- Söyleşiler.Interviezus -

\title{
Hakan Aytekin'le Söyleşi
}

\author{
Kurtuluş Özgen \\ Işkın Özbulduk Kılıç
}

\begin{abstract}
Kurtuluş Özgen: Sinefilozofi dergisinin yönetmen söyleşilerinin bu sayısının konuğu: Yönetmen ve yazar Hakan Aytekin. Sayın Aytekin, Türk belgeselciliğindeSabahattin EyüboğluMazhar Şevket İpşiroğlu (İstanbul Üniversitesi Film Merkezi) ile Suha Arın Ekolü dönemlerini çerçeveleyen 'Kültürel Hümanizma' nın isim babası oldunuz veSuha Arın ekolünün önde gelen temsilcilerinden biri olarak, tarihi ve kültürel konuları ele alan çok sayıda belgesel ürettiniz. Bu çalışmalarınız Türkiye' deki tarihin ve kültürel koruma politikalarının oluşmasına önemli katkılar yaptı. Suha Arın Ekolü'nün en önemli özelliği filmlerin omurgasını bilgi ve belgeyle özellikle akademik bilgiyle inşa etmesidir. Bilgi, belge ve belgesel sinema arasinda size göre nasıl bir ilişki var?
\end{abstract}

Hakan Aytekin: Bilgisiz ve belgesiz belgesel sinemanın yapılabileceğine inanmıyorum. Çünkü belgesel sinema daha kavramın kendisine içkin olarak belgeden söz eden bir sinema. Belge dediğimiz şey içinde bilgiyi barındıran bir şeydir. Çünkü o bir bilginin toplamda bir araya getirildiği onu ifade eden ya da onu temsil eden bir materyal ya da bir durum, bir olaydır. Bu bağlamda bilgiyi belgeden, belgeyi belgesel sinemadan koparmak çok mümkün değil. Ancak şöyle bir durum var. Son yıllarda benim kültürel hümanizma olarak ifade ettiğim dünyadaki değişik belgesel sinema kuramcılarının da özellikle açıklayıcı ya da didaktik noktada ifade ettikleri filmlerde aslında çok yoğun bir şekilde bir bilginin aktarımı söz konusu. Ve bu bilgi daha çok akademik bilgiye yakın olarak ifade ediliyor. Bunun farklı nedenleri var. Belgesel sinema tarihi içinde üstlendiği işlevden belgesel sinemayı gerçekleştirmek için gerekli olan donanıma varana kadar pek çok unsur bizi, açıklayıcı ya da didaktik olmaya zorunlu kılmıştır. Bugünkü belgeselcilerin ya da belgesel üzerine yazanların şöyle bir ön kabulü var gibi geliyor bana: "Sanki ses ve ses kaydı belgesel sinema başladığından bu yana mümkündü ve belgesel sinemacılar tercihen sesi kullanmadılar" gibi. Ben yer yer böyle tuhaf açıklamalara rastlıyorum. Ama bu, teknolojiyle gelişen alanda ses kaydının mümkün olmasıyla erişebilen bir durum. Oysa benim belgesel sinemaya başladığım ve sizin sorularınızda yer alan Suha Arın Ekolü'nün belgesel sinemayla hemhâl olduğu dönemlerde ses ne yazık ki alanda, sinırlı ölçüde eş zamanlı olarak kaydedilebilen ve kullanılan bir şeydi. Ekipte her şeyden önce pelikül kullanılıyordu. Pelikülde ses kaydı yoktur. Sesi ayrıca kaydedersiniz ve stüdyo aşamasında yani laboratuvar aşamasında pek çok aşama geçildikten sonra o ses filme ancak eşlik edebilir. Hal böyle olunca sizin alandan da aktarmak istediğiniz her şeyi doğrudan kaynak kişi aracılığ1 ile kaydetmeniz ve aktarmanız imkânsızlaşır. Bunu doğal olarak stüdyo aşamasına aktarmak zorundasınız. Ve o zamana kadar da yani belgesel sinemanın doğuşundan itibaren, hayatı anlama, tanımlama gibi kaygıların ve o bilgiyle ve anlatılanın çok uzun yıllar bizi çok yanlış yere götüren nesnellik kavramına dayanma kaygısının da yarattığı durumla bir şekilde bilgi de akademikleşti. Ve ister istemez daha çok yönetmenin sözünün olduğu bir form bu: Didaktik form. Baktığımızda katılımcı ya da refleksif belgeselde daha çok varlığı filan tartışılıyor. Ama bu bana göre varsayımsal bir şey. Doğru bulmuyorum. Asıl yönetmenin varlığı kavramaya çalıştığı açılayıcı-didaktik filmlerde tanrının sesi diye bugün aşağılanan şey, yönetmenin kendi bilgisi ya da gerçekliği algılama biçimi. Bunu kabul edebiliriz ya da etmeyiz. Çok tartışmaya girmek istemiyorum. Çünkü bugünkü belgesel sinema modlarına da karşı değilim. Ve ben bugünkü modlarda film üretmeye çalışıyorum ama gerçek çok tanımlanabilir bir şey değil. Yani bunu nasıl aktaracaksınız. Siz ancak gerçekliğin bilgisini aktarabilirsiniz. Bakın üzerine basarak söylüyorum. Gerçekliği değil gerçekliğin bilgisini aktarabilirsin. Bu bilginin 
de akademik bilgiyle örtüşmesi kadar doğal hiçbir şey olamaz. Bu bağlamda Suha Arın Ekolü daha çok akademik kaynaklardan derlenen bir belgeselcilik anlayışıydı. Suha hoca'nın tabiriyle en az üç kaynaktan doğrulanmayan hiçbir bilgi Suha Arın'ın metinlerine veya filmlerinin anlatı yapısına girmezdi. Fakat günümüzde akademik dünyaya baktığımızda son derece referans verici bir akademik dünya var. Yaratıcı değil referans verici hatta üst akademisyenler alt akademisyenleri ne kadar referans verdiğiyle değerlendiriyor. Sizin özgür bir şey söyleme hakkınızın elinizden alındığı dolayısıyla ha bire birilerinin tekrar ettiği bir bilgi yığını size bu üç kaynağı çok kolay sağlıyor. Google'a girin herhangi bir kavramı yazın, yüz otuz üç tane kaynak önünüze dökülüyor. Hepsini bir tezinizde ya da argümanınızda kullandığınızda sizden daha akademik kimse olmaz. Bunun da bir yanılsama olduğunu düşünüyorum. Peki, burada ölçek ne olacak? Ölçek kesinlikle belgesel sinemacının kendi birikimiyle kendi etiği arasında bir yerde duruyor. Ben o yüzden belgesel sinemacıyı, bilgiyi kendisi dışındakinden toplayabileceği ve kendi bakış açısıyla anlatabileceği bir şey olarak görüyorum. Belgenin bir bilgi demeti olduğunu düşünüyorum ama bunun seyirciye aktarılmasının doğrudan gerçeklik değil ancak onu temsil eden bir bilgi kümesi olduğunu söyleyebilirim. Suha Arın'ın ekolü de yıllarca böyle yaptı ben de uzun yıllarca böyle yapmaya çalıştım. Hâlâ farklı modlarda da film üretsem de bilgi benim mutlaka yol arkadaşım, bilgi olmadan hiçbir filmi çekmiyorum. Bilginin arka planındaki çok iyi araştırma, gözlem, tartışmanın alandaki karşılığını bulma ve belki sonuçta bunu tırnak içinde söylediğim "kendi imgelerimize dönüştürme" şeklinde izleyiciye ulaştığını düşünüyorum.

Kurtuluş Özgen: Verdiğiniz cevap bende bir açılama yapma ihtiyacı hissettirdi. Bir de ara soru soracağım size. Didaktik dediniz ama ben Suha Arın'ın ekolünü temsilcilerinden mesela sizin, Hasan Özgen'in, İsmet Arasan'ın didaktik olmayan ve son derece poetik hikâye anlatıcılığı taşıyan pek çok belgeseline tanık oldum. Burada aslında sanırım kıymetli olan bu akademik olarak tanımlamaya çalıştığımız bilginin filmin içerisine katılma biçimi. Ben onu didaktizmden çok uzak görüyorum. Günümüzde ise pek çok belgeselde eksikliğini hissettiğimiz işte bu gerçeklik dediğimiz şeyin bilgisinin taşınmasındaki karşılaştırma imkânı ve onu bir şekilde kontrol etme imkânı. Bu anlamda sizin de temsilcisi olduğunuz ekolün Türk Belgesel Sineması' na getirdiği yönelim, gelenek de diyebiliriz. Bilginin-belgenin belgesel sinemadan aslında bir şekilde ayrıştırılamaz olması. Bilgi ve belgenin belgesel sinemaya içkin olması. Bu yönelim günümüzde gitgide zayıflıyor. Buradan yola çıkarak, az önce bahsettiğimiz ve ismini sayamadığım başka belgeselciler gibi siz de iyi bir hikâye anlatıcısısınız. Bunun köklerini soracak olsak, nerelerden bu hikâye anlatıcılığ 1 sizde oluştu?

Hakan Aytekin: Ben bunu herhalde tahlil etmekte çok zorlanırım ama bana da iyi bir düşünme firsatı sunmuş oluyorsunuz bu soruyla. Bir kere ben ciddi bir sözlü kültür geleneğinin içinden geldim. Bugün belgesel sinemacılar belleğin peşinde koşuyorlar ama bellek çoğu zaman sözle aktarılan bir şeydir. Belleğin aktarıcılığına yazı çok çok sonra eşlik etmeye başlamıştır. Yazının bütün hayatı yaklaşık altı bin yıl kadar ama insanın dünya üzerinde bir varlık olarak kendini bugünkü insansıya benzer şekilde var etmeye başladığı süreç günümüzden yaklaşık dört yüz bin yıl önce, homosapiens dediğimiz konuşan insanın varlığı ise elli bin yıl önce. Yani şimdi kalkıp da altı bin yıl önce ile karşılaştırdığımızda elli bin yıllık en azından konuşan insan var ve konuşan insanın geleceğe, kendisi dışındakilere bildiği bilgiyi aktarması ancak dille ve sözle mümkündü. Sözdü taşıyıcı olan. Dünyada olup bitenleri ve aslında kendi varlığını sorguladı̆̆ında yorumlayabileceği kitaplar yoktu, kaynaklar, Foucault gibi insanlar yoktu. O zaman başvuracağı tek şey kendi yorumsamaları ve dünyada gördüklerini yani kendi gerçekliği içinde gördüklerini yorumlama gücüydü. Başka bir şey değildi. Ve insanlar bunu sözle aktardılar. Ben çok mutluyum. Ben sözlü geleneği Anadolu'nun en son kaybetmiş gruplardan birine üyeyim. Ben göçer kültürden bir topluluğun devamı olan bir aileden geliyorum ve o aile de benim çocukluğumda hâlâ yarı göçer vaziyetteydi. Yazlık ve kışlık olarak yaşayan bir aileydi. Dolayısıyla ben kendi sülalemde o kadar çok sözlü bilgiye maruz kaldım ki, o kadar birbirine aktarılarak anlatılan deneyime tanık oldum ki, bu benim bir şekilde zihnime yerleşti diye düşünüyorum. İkinci unsur ise kendimi en çok şanslı hissettiğim noktalardan biri olan babam. Gerçekten. Çünkü babam yüzyılın başlarında, ilk çeyreğinde, Türkiye Cumhuriyeti'nin yeni kurulmaya başladığ1 tarihte doğmuş birisi. $O$ tarihlerde yokluğun ve yoksulluğun içinde, çok fakir bir ailede babasız büyümüş. Yani tutunacak hiçbir dalı yok. Ama bu adam, Türkiye' nin çokça tartışılan bir eğitim kurumunun içine girme şansını 
yakalamış. Köy enstitüleri. Ve köy enstitülerinin ilk mezunu babam. Böyle bir babanın çocuğu olmak beni ister istemez o belleğin taşıyıcısı konumuna ve bugünün en önemli unsurlarından biri olan yazıyla da yan yana getirdi. Ben gözümü açtığımda bizim evimizde kitaplık vardı. Ben birkaç yıl önce yazlığa kitaplarımızı götürdüğümde kitaplık aradım satın almak için. Kitaplık kavramını mobilyacılar bilmiyor. Çünkü kitap diye bir mevhumu bilmiyor. Herkes o televizyon konan yerler var ya kitaplık diye, onu gösterdi bana. Şöyle bir baktım benim tiyatro kitaplarım bile oraya sığmaz. Hani bırak diğer kitapları filan. İşin özü, o adam bana dünyayı taşıdı yazıyla, taşıyor da. Ben dünyaya gözümü açtığımda o kitaplar vardı ve belgeselciliğimin özünü ben oraya bağlıyorum Kurtuluş hocam. Köy enstitülerinden mezun olduğu o dönemde yani bahsettiğim yıl altmışlar, ben biraz eskiyim size göre. Altmışların yazılı alanına baktığınızda, edebiyat alanına baktığınızda çok ciddi şekilde köy enstitülerinden yetişmiş bir yazar grubunun Anadolu'yu algilama ve anlatma biçimlerini görürsünüz. Yani Fakir Baykurtlar veya köy enstitülerine başlı başlına karşı çıkan Kemal Tahirler... Bunlar benim çocukluğumu bilgiyle inşa etti. Ve dolayısıyla ben hayatı sözle ve yazıyla tanıdım. Benim görüntüyü tanımam lise yıllarıdır. Televizyonla hemhâl olmam... Evet televizyon ben yedisekiz yaşındayken yayına başladı Türkiye' de ama televizyonun bizim evimize girmesi ben on dört yaşındayken gerçekleşti. Ben görüntüyü o zaman görmeye başladım. Lise ikideyim, bir gün televizyonda bir şey oynuyordu, böyle televizyonun tek kanal olarak sınırlı gün ve sınırlı sayıda yayın yaptığı bir dönem. Siyah beyaz. Arkeolojik bir şey oynuyor, adını bile koyamadığım bir şey. Kitlendim kaldım. Sonuna kadar seyrettim. Birinci bölümün sonu yazdı. Çok mutlu oldum. Demek ki haftaya ikinci bölümü izleyeceğiz diye. O zaman televizyona periyodik olarak dikkat ederlerdi tabi. Özetin özeti, dünün özetinin özeti falan gibi şeylerin olmadığı daha nitelikli sınıflandırılabilecek bir yayıncılığın olduğu yıllar. Haftayı bekledim ve haftaya o filmi izledim fakat bu sefer son yazdı. Sadece iki bölümmüş ama oradan bir şey benim aklımda kaldı: Yönetmen Suha Arın diye bir şey. Fakat ben o filmi izledikten sonra kameraman olmaya karar verdim. Ben yönetmenin ne işe yaradığını da bilmiyorum, en son onun adı büyük yazıldığı için benim aklımda kaldı. Ben kameraman olmaya niyetlendim ve üniversite sınavına girerken Türkiye' de o zaman sadece altı tane basın yayın yüksekokulu vardı, şimdiki gibi iletişim fakültesi yoktu. Ve güzel sanatların içinde sinemayla ilgili bir alan da yoktu hatırladığım kadarıyla. Ben sadece altı tercih yaptım. Üniversite sınavında ben ilk tercihim Ankara Universitesi Siyasal Bilgilere bağlı olan Basın ve Yayın Yüksekokulu'nu kazandım ve çok da dehşetli bir puanla kazandım. Herkes benimle dalga geçti. Neyse girdim ve orada ilk tepkilerim bir düş kırıklığ1 oldu çünkü çocukların hiç kamera göremediğini anladım. Kamerayı böyle bir uzay geometrisi gibi anlatıyorlardı. Dedim eyvah bunların hiç sinemayla filan ilgileri yok ben buraya niye geldim dedim ama şans, araştırma duygusu ve o tutku beni yolumdan çıkarmadı. Bir gün girişteki o öğrenci duyuruları panosunda bir duyuru gördüm. Dördüncü sınıflara bir uygulama dersi için hoca çağrıda bulunuyordu. Altında inanamadım bir şey yazıyordu: Suha Arın yazıyordu. Gittim direkt kapısını çaldım. Baktı böyle hoca: "Buyurun" dedi. "Ben panodaki yazı için geldim" dedim. "Siz kimsiniz? Ben sizi tanımıyorum, derslere pek girmiyorsunuz" dedi. "Ben o sinıfta değildim" dedim. "Kaçıncı sınıfsın?" dedi. "Birinci sınıfım" dedim. "Gel bakayım şöyle" dedi. O gel bakayım şöyle, işte beni o ekolün üyelerinden biri haline getirdi. Demek istediğim şey şu; söz yazıya, yazı da ilgiye ve meraka dönüştü. Hayatı algılamaya başladık ve ben çok politik bir ortamdan geçerek geldim. İki darbeyi 12 Mart ve 12 Eylül'ü çok bilinçli şekilde yaşadım. Bütün o politik ortam, kendi evimizin politik bir ortam oluşu, babamın yazarçizer olması ve çevresinde yazarçizerlerin varlığı, Anadolu' nun romanlarla kentlere aktarılmaya çalışıldığı yeni bir aydın modelinin kurulmaya çalışıldığı bir dönem. Yani burada ben kurmaca sinemaya da yönelebilirdim ama o kadar çok hayatın içinde oldum ve o göçer kültürün izlerinde yaşadım ki hayat bana çok daha cazip geldi. Benim şu anda defterlerim var. Ortaokuldayken yaylada, köyde kelimeler derlemişim. Ortaokul çocuğu için çok ileri bir şey. Ha, bir merak varmış. Biraz uzattım ama bunların toplamından bir belgeselci mesleğine doğru, böyle bir formasyona doğru geliştiğimi görüyorum.

Işkın Özbulduk Kılıç: Hocam ben aslında sizi tekrar gerçeklik meselesine döndüreceğim biraz da detaylandırmak isteyeceğim. Çünkü belgesel meselesi ne zaman tartışılsa bir hakikat meselesi ardından geliyor. Dolayısıyla da hep tartışılacak, hiç bitmeyecek belki hem de hep önemli olacak bir mesele. Belgesel çekerken bir gerçeğin peşinden gidiliyor ama bu sizin gerçeğinizle kuşanıyor dolayısıyla bunu zaten az önce ifade ettiğiniz gibi bilinen bir 
gerçekliğin olması yani gerçekten kastedilen bir gerçek olması aslında mümkün değil tam olarak. Ama bir yandan da mümkün çünkü o da başka bir gerçek. O yüzden ben aslında sizin Parrhesia kavramıyla ele aldığınız makaledeki fikirlerinizi biliyorum ama okuyucularımızla paylaşmanız için bir kez daha soruyorum. Siz bu belgeselleri çekerken daha çok hangi gerçek üzerine, kimin gerçeği üzerine yola çıkıyorsunuz? Kendi gerçeğiniz mi, ortada bulunan gerçek $\mathrm{mi}$, anlatmak istediğiniz kişinin gerçeği mi? Yani ya da gerçekle ilişkinizi tam olarak nasıl kuruyorsunuz onu merak ediyorum. Bir de bir gerçeğin peşine düşerken de örneğin bir şiirin, bir mekânın peşine düşerken de bunu çekmek ya da anlatmak gerekliliğine dair sizi ne ikna ediyor?

Hakan Aytekin: Sevgili Işkın hocam, bunlar gerçekten belgesel sinemanın içinde her zaman tartışılan hiçbir zaman da sonuçlanmayan sorular. Hep farklı yerlerinden yaklaşabiliriz farklı yerlerinden cevaplayabiliriz ama şu da değişmez bir gerçek ki bizim başımız gerçekle dertte. Evet, gerçek denen bir şey var. Biz de buna çoğu zaman sı̆̆ınıyoruz. Sizin tabirinizle onu kendi gerçekliğimizle kuşatıyoruz veya kuşanıyoruz. Bu karşılıklı bir ilişki. Sonuçta ortaya bir şey çıkıyor, bir şey bu. Ne kadar gerçek bunu tanımlamak çok mümkün değil. Ölçülebilir bir şey değil. Çünkü şimdi bizim dışımızda bir şey var. Ve biz ona burnumuzu sokup onu başka bir şeye dönüştürüyoruz. Yani o klasik gerçek kavramını anlatırken söylenen ağacın yaprağı meselesi işte, ağacı getirip oraya koymuyoruz biz. Oraya ağacın görüntüsünü getirip koyuyoruz ya da o ağacın neresini çektiysek onu getirip koyuyoruz. Yani yaprağını mı kökünü mü gövdesini mi, onu siyah beyaz mı yeşil mi gösterdik, gece mi çektik gündüz mü çektik, yapraklı mı yapraksız $\mathrm{m}$ çektik gibi yüzlerce binlerce milyonlarca farklı durumun içinden biz o bir şeyi çekip başka bir şey olarak getiriyoruz insanların karşısına. Burada çok uzun yıllar sığındığımız ama sonra dehşetli şekilde o kavramdan uzaklaşmaya başladığımızı belirterek sözü nesnellik kavramına getirmek istiyorum. Çok netameli bir ifade: "Belgesel sinemanın nesnelliği." Evet, orada nesne var duruyor. Belki biz o nesneyi getirip izleyicinin karşısına koyuyoruz. Ama bir başkası da çıtığında, o nesneyi daha en baştan belki de hiç tercih bile etmiyor göstermek üzere. Velev ki tercih etti, bu sefer benim gösterdiğim gibi değil bambaşka bir şekilde gösteriyor. Ama ikisi de aynı. Aynı olgu, aynı nesne, aynı durum... Ama bunun görünür hale gelmesi çok başka bir şey olmaya başlıyor. O anlamda çok netameli. Fakat ben hanidir belgesel sinema tanımı yapılabilir mi diye bakıyorum. Bir sürü insan tanımlar yapmış. Çok geliştirilmiş tanımlar var. Grierson'la başlayan belki de en çok kabul gören tanım daha çok bizim ayağımızın altında dolaşıyor. Bütün onların toplamına baktığımda ben sadece şunu söyleyebiliyorum. Benden önce bana rağmen var olan benim temel kriter noktam bu: "Benden önce bana rağmen var." Bir kere bu benim yarattığım bir şey değil. Benden önce yaratılmış bir şeyi ben ele alıyorum. Ha, ele aldığım andan itibaren beni öznelliğim başlıyor. Bir kere ben onu görüyorum, ben onu seçiyorum ve ben onu görmek istediğim gibi göstermeye çalışıyorum. Yani tamamen öznel bir şekilde o benden önce var olanı göstermek istiyorum. Bu anlamda zaten hakikat dediğimiz şey o nesnel gerçekliğin öznel olarak bir yansıması değil midir? Dolayısıyla belgesel sinema da bu anlamda hakikati aktarırken aslında son derece yönetmenin öznelliğiyle anlatıyor. Bu anlamda, gerçek artık kendi o nesnel dünyasından kopup yönetmenin gerçekliğinin bir parçasına, onun bir gerçeği bir bilgi haline getirişine dönüşüyor. Bu tabii ki açıklaması da zor savunması da reddetmesi de zor bir durum. Çok paradoksal bir şey bu. Ama burada tabi başka parametreler devreye giriyor. Neden onu çekmeye değer bulduğunuz? Sizi ona yönlendiren ne? Burada bir kere kendi yaşam deneyiminiz, o güne kadar biriktirdikleriniz, dünyaya bakış açınız, dünyayı görme, algılama, algılatma biçiminiz bütün bunlar bir araya geldiğinde ve sizin çıkış noktanız, sizden önce size rağmen var olansa zaten yolunuz belgesel sinemadan geçiyor. Kurmaca sinemada bu olmaz mi olur tabii ki olur. Ama orda Nichols' 1 n deyimiyle siz onu o gerçeğin yaşanmış haliyle bir alegoriye dönüştürüyorsunuz. Artık sizin karşınızda işlenmeye değer herhangi bir kurulabilir yapıya dönüşüyor. Yani gerçek tamamen unutulmuş, bir kenarda kalmış bir ögeye dönüşüyor. O bağlamda, beni gerçeği anlatmaya ikna edebilecek herhangi bir şey, onun belgesel filme dönüştürülmesi konusu. Ki ben burada ustam Suha Arın'la çok ciddi çatışırdım. Çok ciddi tartışırdık. O "her şeyin belgeseli çekilmez" der. Çok Ortodoks, çok katı bir tavrı vardı. Bense her şeyin belgeseli çekilebilir diye tartışırdım. Hatta bana şunu söylerdi: -özellikle etik meselesine lafı getirmek için- "Bir Alzheimer hastasını çekemezsiniz ya da Alzheimer'ı çekemezsiniz." Yani kavram olarak onu ileri sürmüştü bir tartışmamızda. Ya, ben Alzheimer olgusunu çekerim ama illa da bir Alzheimer'lı hastayla da çekmek zorunda değilim ki. Yani o olguyu ben başka şekilde aktarabilirim. Başka araçları gerçekçi kullanabilirim. Bu 
bağlamda, -ben özellikle son yıllarda bunu daha çok yapmaya başladım tabi- geriye doğru dönüp baktığımda da bunu gördüm. Bu biraz da Suha Arın Ekolü'nden gelen bir şey. Suha Arın' in ekolünde bir konuyu anlatmaya kalktığımızda o konuyu o olguyu bir omurga üzerine kurarak anlatırız. Kurtuluş hocanın başta sorduğu bilgi kavramı burada tekrar devreye giriyor. Bir bilgiyi o kadar poetik bir hale getiririz ki, o kadar görüntüyle hemhâl hale getiririz ki, o orda artık bir bilgi kümesi, bir bilgi yığını olmaktan çıkar. O, izleyici de bir duygulanıma yol açacak bir şeye gelir. Yani bizim ortaya döktüğümüzz kodlarla, izleyici de o kodları alarak artık kendi gerçekliği içinde onu tartışır muhasebesini yapar. Ve artık yeni bir formatta o da gerçeği bir kere daha dönüştürerek kendisi algılamaya başlar. Dönüp bakıyorum şimdi kendi filmlerime, ben bir mektuptan hareketle kendi belgesel sinema alanımda kocaman bir fenomen yarattım. Yani Süryani kültürü üzerine çalışan belki de dünyada bu konu üzerinde en çok çalışmış belgeselcilerden biriyim, belki de tekim. Onu çok iyi bilmiyorum. Çekenler var ama benden daha az daha çok onun muhasebesini yapamıyorum. Beni oraya çıkaran şey bir mektup, sadece bir mektup... Bir Süryani'nin mülteci olarak Hollanda'ya gidip orada kalıp sonra hayatını Hollanda' da sürdürüp ama çıtığı coğrafyayı yani kendi çıkış gerçeğini unutmayıp bu özlemini dile getiren bir adamın televizyona yazdığı bir istek mektubu. Bir istek mektubu bana etnisiteyi anlatabileceğimi gösterdi. Kültürü anlatabileceğimi gösterdi. Kültürel hümanizmanın en önemli yansıması olan kültürel sürekliliğin ne olduğunu anlatmaya yetecek bir malzeme olduğunu gösterdi. Göçü anlattırdı bana. Yani o kadar çok şeyi anlattırdı ki. O yüzden bir şiir beni bile heyecanlandırabiliyor. Çünkü şiir çok da öyle korkulacak, ürkülecek bir şey değil tam tersine besleyecek bir şey şiir. Ve ben özellikle bu son yaptığım filmi de şöyle bir dile getirsem daha iyi anlatmış olacağım kendi derdimi. Biz genellikle belgesel film çekileceği zaman hep işte o saf belgeye yöneliyoruz. İşte bir belge olursa onun filmini çekiyoruz. Bu da kendi içinde çok tartışmalı. Belgelerin de kendi içinde ne kadar gerçek olduğu ayrı bir tartışma konusu. Yani oralara girersek içinden çıkmayız ama şunu söylemek istiyorum ya bir imge, örneğin bir şiirin satırlarına sızan "kepenkli dükkânları ve siftahı olmayan bir çă̆" sözünün imgesi bana bir belgesel film için çıkış noktası niye olmasın. Bu soyut bir şey. Siftahsızlık ve kepenkli dükkânı olmayan bir çağ meselesi. Bu aslında sosyolojik olarak kocaman bir tarihsel dönemi anlatan bir şey. Anlatmakla kalmıyor bir de bugünlerle karşılaştırma fırsatı veriyor. Olmayan bir şeyin demek ki olan bir zamanı varmış. Olan zaman da kepenklilik ve siftahlılık neymiş, bunun tanıklığı nerde yatıyor? O zaman bir şairin kendi yaşam deneyimi ve o yaşam deneyiminin yer aldığı o mekân o space benim için bir belgesel film yapmaya yeterli oluyor. Dolayısıyla ben, hep şu ana kadar yaptığımız ya da hep yapmaya çalıştığımız rota olan belgeden imgeye doğru gitmek yerine bu sefer imgeden belgeye doğru gitmeyi denedim ve sonra dönüp baktım aslında hep genelde de böyle yapmışım. Hep o soyut olan, imge olan şeyleri düşünmüşüm ama o imgenin belgeye çok iyi tekabül ettiğini ve benden önce bana rağmen var olanı anlatmak için iyi bir fırsat olduğunu gördüğüm an ben ikna oluyorum Işkın hocam. Bilmiyorum anlatabildim mi?

I.Ö.K: Çok güzel anlattınız hocam. Burada bir açıklama daha isteyeceğim. Dediniz ki imgeden belgeye gittim. Aslında siz de ifade ettiniz. Duygunun belgeseli. Yani belge üzerine değil de aslında duygular ve duygulanma üzerine bir belgesel. Belki de duyguları belge edinen bir belgeselcisiniz. Belki de bu böyle kavramlaştırılabilir. Özellikle son filminiz için belki ama diğerlerinde de var bence. Sizin belgeseliniz, daha duygu merkezli belgesel olabilir. Duygunun çok da küçümsenecek bir mevzu olmadığı sizin sayenizde bir kez daha ifade edilmiş olacak. Yani gerçek duygunun da belgeseli var diyebilir miyiz?

Hakan Aytekin: Tabii ki. İnsan davranışlarına nasıl yansır? Yani eliyle koluyla eylemiyle yansır. Ya da zihinsel olarak duygulanımı daha sonra eylemlere yol açar. Ben bu anlamda, belgesel sinemanın propaganda ile arasındaki sınır için de önemli bir noktanın duygu olduğuna inanıyorum. Çünkü duygudan kopup sadece var olan bir ideolojiyi kanitlamaya dönük hale geçtiğimiz andan itibaren yaptığınız iş artık propaganda tarafına daha yakın durmaya başlıyor. Ama siz duyguyla dünyaya bakış açınızı, kendi ideolojinizi izleyiciye, karşı tarafa aktarırsanız bu artık propaganda olarak değil karşı tarafın bir duygulanım içerisine girmesi ve karşı tarafın yeniden sorgulaması, yeniden dönüştürmesi için bir fırsata dönüşebilir. Zorlayan bir yöntem olarak ya da onu sloganlaştırarak değil gerçeğin, tırnak içinde gerçeğin gücünün, o insanda kendini sorgulama, o olguyu da sorgulama ve o olgu hakkında farkındalığı bir basamak ileriye taşıma fırsatı yaratıyorsa yani propaganda olmaktan geçip karşı tarafa bir bilginin 
duygu aracılığı ile ulaştırılmasını sağlıyorsa bu belgesel sinema için bence en önemli anlatma biçimi ve en önemli kazanç. O nedenle de ben kalkıp mesela filmlerimde, özellikle Süryaniler konusunda yaptığım filmlerde bazen çok sert eleştiriliyorum. Bana soykırımı anlatmıyorsun diyorlar. Ben soykırımı da anlatırım ama benim anlatmak istediğim şey; bu filmde göçün dinamikleri ve o göçün dinamiklerinin aradan otuz yıl geçtikten sonra insanların hafızasında yani dünyasında nasıl yer ettiğini anlatmak, aradan geçen otuz yılda onların o bilgisi ve deneyimi nasıl dönüştürdüğünü anlatmak. Bugünden geçmişe nasıl bakıyorlar ben bunu anlatmak istiyorum. Benim derdim niye göçtü de o oldu da bu oldu da falan diye sert eleştiren insanlara cevap vermek için filmimi sloganlaştırmam, sloganlaştırmayacağım da. Ama bir gün kalkar ben soykırım filmi yaparım o zaman bana o soruyu sorun. Şimdi bana bu soruyu sormayın. Ben "Işık Sesini Arıyor" diye bir film yaptım. Işık kim, ses kim, aramak ne üç tane tuhaf şey var burada. Işık hem görülebilir hem görülemeyen bir şey. Hem soyut hem somut. Ses hayatta göremeyeceğimiz bir şey ama gösterilebilir bir şey. Aramak başlı başına zaten soyut bir şey. Benim kastettiğim şey şu: Bilgi dedi Kurtuluş hocam, ilk soru olarak ben ilk önce oturur bakarım. Süryaniler kim, nedir, ne oluyor, ne bitiyor? Ben eğer Süryanileri anlatacaksam Süryanileri önce ben bilmek zorundayım. Dolayısıyla ben literatürde erişebildiğim, gücümün yettiği, aklımın yattığı kadar okudum. "Tanrı 1şıktır, onda hiç karanlık yoktur" diye Incil'de bir cümle yakaladım. Bu bir bilgi. Tanrı ışıktır orda hiç karanlık yoktur. Nerede, İncil' de yazıyor. Tamam, koyduk bir kenara. Somut hale geldi. Peki, bu ışı ğı ilk defa yani Hristiyan öğretisi için ilk defa fark eden ve İsa'nın öğretisinin peşine takılanlar Süryaniler. Bu da başka bir akademik bilgi. Ben bunu da araştırmalarda görüyorum. Birleştirmeye başlıyorum. Işık, Süryanilerin varlığı ve İsa' nın peşine takılıp giden bir halk, en azından Süryaniler ne sorusu, bugünkü en çok akıl fikir birliğine varılan yerlerden biri. Tartışmalar çok yoğun olmakla beraber çıkış yeri neresi, Kuzey Mezopotamya ve bizim Güneydoğu Anadolu bölgemiz hatta Doğu Akdeniz dâhil olmak üzere. Süryanilerin yayılım alanı orası. Peki, bugün orda onlar var mı? Yok. Işık olgusu var mi? Var. Ses olgusu var mı? Var, cilız. Yani o tanrı burada kendi sesini ariyor. Buradaki Süryanileri arıyor. Kendisi var ama o sesi duyamıyor. Buradaki o şey kaybolmuş o kültür o halk kaybolmuş. Ben o zaman o akademik bilgiyi poetik bir hale getirme çalışıyorum. Süryaniler nerde diye düz bir cümle kuracağıma 1şık sesini arıyor diye kuruyorum. Ya da "Yarına Bir Harf" dediğimde ben bir sürü imgeyi bir araya getiriyorum. Burada şeyi de görebilirsiniz ben Hristiyan biri değilim, Süryani hiç değilim. Benim içinde büyüdüğüm kültür Müslüman bir kültür. Bir harf öğretenin kırk yıl kölesi olurum cümlesiyle büyüdüm ben. Hadi buyurun bakalım. Ben Müslüman söylemindeki bir cümleyi Süryanileri anlattığım bir filmin içinde imge olarak kullanırım. Bir harf. Ve yarına bunu nasıl aktaracaksın. Dolaysıyla bilgi bu bağlamda beni heyecanlandıracak bir olguyla bir şekilde bu filmleri yapmaya götürebiliyor beni, sevgili hocalarım. Bilmiyorum biraz konuyu belki dağıttım ama örneklendirmekte yarar olduğunu düşündüğüm için.

I.Ö.K: Teşekkürler hocam.

Kurtuluş Özgen: Aslında üçüncü soruyu açmış oldunuz biraz. Bahsettiğiniz üç tane belgeseliniz var Süryanilerle ilgili. Işık Sesini A rıyor (2001), Yarına Bir Harf (2007) ve EnstANtane AN (2020). Ki EnstANtane AN filmini ben şöyle yorumluyorum: Roland Barthes Punctum diye tanımladığı delici imge, film tam o fotoğraftaki Punchtum' u deşifre eden açığa çıaran bir film. $\mathrm{Bu}$ anlamada ayrıca kıymetli buluyorum bu filmi. Zor da bir deneme. Fotoğrafik imgeden derinlemesine bir anlatı kurmak... Bence yaptığınız çok kıymetli. Bu üç filmde bana göre bellek ve duygu arkeolojisi yapıyorsunuz. Belgesel sinemacı olarak bellek-hafıza kavramına nasıl yaklaşıyorsunuz?

Hakan Aytekin: Çok geniş bir soru hocam. Ama en azından şöyle belki biraz daha zenginleştirebiliriz bu durumu. Belgesel sinemanın son yılarda en büyük iddialarından biri toplumsal hafızayı oluşturmak. Şimdi çok büyük bir iddia. Ama toplumsal hafıza sadece belgeleyerek mi oluşur? Bunun bir kere belgelenmesi, aslında başlangıç noktası, çok çok küçük bir alanı belgelemek. Bunu siz eğer başka alanlara da sirayet ettirebilirseniz buradaki bilgi yani bir film olarak kalmayıp o film bir kitaba dönüşebiliyorsa oradaki olgu tabii ki filmin kendisini kastetmiyorum o da olsa zararı olmaz, o da hafızaya katkı demektir. Bu bir makalenin konusu olabiliyorsa, bu bir tezin başka anlatı araçlarıyla başka bir anlatı formuna gelişiyorsa o zaman büyümeye başlar. Ve arkeolog olarak siz birisinin belleğinden 
çıkardığınızı başkasının belleğinden çıkardıklarıyla yan yana getirdiğinizde aslında toplumsal hafıza oluşmaya başlıyor. Tek tek hafızalar kuşkusuz çok önemli ama birden çok hafızayı bir araya getirdiğinizde o zaman toplumsallaşmaya başliyor. Çokluk duygusu, o zaman birbirine benzeme duygusu, birbiriyle karşıt olma duygusu, birbirini çürütme duygusu ortaya çıkıyor. Hayat tek şekilde yaşanmıyor işte gerçeğin tanımında da söylüyoruz. Baktığımız yere göre gerçek o kadar farklılaşıyor ki. Benim “EnstANtane" filmim, hocam çok teşekkür ederim yani Puncthum benim zaten bu filme başlama nedenim o yüzden de filmin en başında Barthes'i anarak başliyorum zaten. On sekiz kişinin olduğu bir fotoğraf bu. Ve bu fotoğraf o on sekiz kişi artı onu çeken on dokuzuncu kişi... Ve o sırada görmediğimiz çerçevenin dişında kalan dünya tarafından bilinen bir gerçek var. Süryaniler bir mekânda o fotoğrafı hatıra fotoğrafı olarak çektirmişler. Ama aradan otuz yıl geçmiş. O otuz yılda bu insanlar yeni gerçeklerle yeni gerçekliklerle karşılaşmışlar. Bir kere o fotoğrafın çekildiği alandan uzaklaşmışlar. Başka dünyalara gitmişler. Oralarda yaşar hale gelmişler, orada çoluğa çocuğa karışmışlar. Dolayısıyla otuz yılda biriktirdikleri bir deneyim dünyası var. Unutmalar var, hatırlamalar var özellikle hatırlamak istenmeyenler var. Bellek mesela hep tartışılıyordu, belleğin içinde unutmak istediklerimiz hiç tartışılmıyor. Bellek, sadece dışarıya taşan kısmıyla belleği oluşturduğumuzu varsayıyoruz. Tamamen eksik bir yaklaşım bu. Çünkü bizim anlattıklarımız, hatırladıklarımız, yaşadıklarımızdan çok daha az olan ve bugünün süzgecinden geçerek dışarı vurulanlar. O anlamda belgesel sinema iyi bir firsat. Ne kadar farklı aynı olguyu ele alanlar ne kadar farklı türde bellek arkeolojisine başvurursa toplamda bir toplumsal tabanı geniş bir hafıza oluşturabiliriz. Bunları oluştururken bunun kurumsallaşması da hepsinden önemli bence. Sadece insanların belleği ve onun literatüre geçmesi değil ki. Bunun daha ileriye taşınabilir olması lazım bunun üzerine gelişmesi lazım. Mesela, Türkiye'nin son yüzyıldaki yaşadığı en önemli toplumsal olaylardan biri büyük mübadele. Yaklaşık iki milyonun insanın yer değiştirmesi. Yüzyılın başında iki milyon insan çok ciddi bir rakam. Şimdi buradan Yunanistan'a göçenler var. Yunanistan'dan Türkiye' ye göçenler var. Topladık bunları tek tek dinledik. O onu dedi bu bunu dedi. Eee? Lozan Mübadilleri Derneği şurada yirmi senedir falan var. Tam tarihini bilmiyorum ama bu $1924^{\prime}$ de yaşanan bir olay. Yani aradan nerdeyse seksen yıl geçtikten sonra bunu kuramsallaştırmaya başlıyorsun. Dönüp baktığınızda akademinin içinde de bunları göremiyorsunuz. Bu bağlamda akademik olarak bunun daha kurumsal hale getirilmesi lazım. Toplumsal bellek olgusunun tamamen işe yaraması için. Kim ne derse desin devlet kurumları toplumsal hafızanın bir parçası olmak zorunda. Devlet bizim dışımızda bir şey değil ki. Neden benim hafızama sahip çıkmasın ki devlet. Yani bu benim devletçi bir adam olduğum anlamına gelmiyor ama benim kurumlaşmam için benim kaynağımın garanti altına alınması lazım. Devlet dediğim şey bana bilmem ne bakanlığı, bilmem ne yapsın diye değil. Devletin kaynaklarıyla beslenen kurumların benim toplumsal hafıza derdime ortak olması lazım. En başta üniversite olmak üzere. Kamu televizyonu yok ya! Ben toplumsal belleği belgeledim koydum, ne yapacağım? Hepimizin belgeselcilerin belki amiyane bir tabir olacak ama çeyiz sandığında hafızalar var ama hiçbirimiz evlenemedik. $\mathrm{O}$ sandığ 1 çeyizi bir yere götüremedik. Arada bir gelenlere bak yüzümü göstereyim sana diye işte özel toplantılarda falan çeyizi açıp gösteriyoruz ama hâlâ talipli bir damat çıkıp da bize koca olmadı. Cinsiyetçi bir ifade ile söyledim ama niyetim cinsiyetçi değil. Sadece bir analoji kurmak açısından kullanıyorum. Çeyiz sandığı var ama çeyizden kimsenin haberi yok. Sadece çeyizi işleyenin, gece gör kandilde kanaviçe işleyenin haberi var. Bu da ne yazık ki toplumsal bellek konusundaki iddiamızın çok da ileriye taşınamadığını gösteriyor ama iyi ki varız, iyi ki belgesel sinemacılar bu işin ucundan tutuyor. Belki bir gün kültür bakanlığ gibi bakanlıklar falan da özellikle bu toplumsal bellek meselesine özel ilgi duyabilirler. Bu konuda çalışan STK'lar artabilir. Bu konu bir de disiplinler arası olmak zorunda. Tek boyutlu asla olmaz. Ben de gidip bir göç filmi nedeniyle röportaj yaptığım da benim kadar soru sorabilir. Birinin benim sorduğum sorulardan hareketle kalkıp hukuk çalışması yapması lazım geriye dönüp. Göçün hukukunu çalışması lazım birilerinin. Hafıza anlamında çalışsa bile her kimin hafızasında ne kaldı bunu çalışsın. Bir ekonomist göçün yarattığı travma kadar kazancını anlatsın bana. Bugün göçen Süryanilerin muhteşem bir hayatı var. Göçtükleri an ki hayatlarıyla karşılaştırdıkları zaman. Ama mal mülk sahibi olmak, ekonomik olarak daha iyi bir yerde olmak, sosyal olarak daha iyi olmak anlamina geliyor mu? Bir sosyologda otursun bunu çalışsın. Göçün psikolojisini çalışan kim var. Ben hadi belleklerden aniları topladım ve manipüle ettim varsayalım. Birilerinin çıkıp bunu disiplinler arası olarak zenginleştirmesi gerekir ki o toplumsal sözcügünün hakkını verelim. Kurtuluş hocam bilmiyorum ne dersin. 
Kurtuluş Özgen: Katıllyorum hocam. Bir de şunu belirtmekte fayda var. Belgesel sinemacılar olarak bizlerin yani iki tane önemli misyona sahip olduğumuzu doğamız gereği düşünüyorum. Bir tanesi görünmeyeni görünür kılmak ikincisi de tarihe şerh düşüyoruz. Hakikaten bilgi belge bırakıyoruz. Pek çok belgeselinizde bilfiil tanıklık ettiğiniz ve izleyiciye taşıdığınız pek çok coğrafya, yapı ve insan artık yok. Ama siz belgelediniz onları.

Hakan Aytekin: Ne yazık ki. Ben onu hep şöyle bir ironi ile şey yapıyorum bazen. İçimdekini döküyorum. Bazen dalga geçmek için ama çoğu zaman içime akan bir acı olarak ifade ediyorum. Yavuz Turgul'dan mülhem bir ifade "bu seyredilmeyen belgesellerin unutulmaz yönetmenleri olarak tarihe geçeceğiz" diyor. Çünkü belgeler tarihe geçmiş olarak artık biri merak ederse, bunu da Hakan hoca yapmış bunu da Kurtuluş hoca yapmış bunu da Ahmet yapmış Mehmet yapmış derse o zaman hatırlanırız.

Işkın Özbulduk Kılıç: Yine makalenizde ele aldığınız Parrhesiastes'in doğruları söylemesi, aynı zamanda bir risk alması anlamına gelmekte, bu hususta belgesel sinemacı bir Parrhesiastes ise eğer aldığı riskler neler?

Hakan Aytekin: Belki izleyicilerimize ve okuyucularımıza Parrhesiastes kavramını birazcık açılamakta yarar var. Antik yunanda doğruyu söyle kavramı olarak da bunu yapan kişiyi kasteden bir terim bu. Foucault bu konuda hakikati söylemek doğruyu, söylemek üzerine oldukça zengin ve derin bir tartışmayı açıyor. Ben de bu bilgiye rastladıktan sonra biraz belgesel sinema ile bu kavram arasında bir bağ kurulabilir mi acaba diye düşündüm. Benimkini aslında bir deneme, bir iddia olarak söylemek istemem ama en azından hani üzerine tartışabiliriz, üzerine düşünebiliriz. Belgesel sinemada bu kavram kendine bir karşılık bulabilir. Çünkü Parrhesiastes doğruyu söylemek üzerine kurulu ki doğru çok netameli bir kavram zaten. Doğruyu tanımla deseniz ben tanımlayamam vekimsenin dedoğruyu tanımlayabileceğini sanmiyorum. Ama Antik Yunan'da ve Foucault'nun söylediğinde beni yakalayan şey şu oldu şimdi kamusal alanda birisi çıkıyor ve doğruyu söylüyor. Bunun ne kadar doğru olup olmadığı tartışması üzerinden geliştiriyor kavramı Foucault ve diyor ki: Bu kişi onu doğru bildiği için değil o anlattığı zaten doğru olduğu için aktarır. Bu çok önemli bir şey. Çünkü doğru bildiğiniz dediğiniz andan itibaren öznellik işin içine girmeye başliyor. Ben öyle biliyordum abi ne yapayım işte Ahmet hırsızd. Ben öyle biliyordum. Hayır değil. Eğer ben Ahmet hırsızdı diyorsam Ahmet gerçekten hırsız olduğu için hırsız diyorum. Kavramın Türkçe karşılığını ben bu şekilde algıladım. Ve bunu belgesel sinemaya uyarladığımda şunu diyorum; şimdi belgesel sinemacı bir şeyi anlattığında her ne kadar onun öznel bakışıyla anlatılmış olsa da benim belgesel sinema tanımından cesaret alarak bunu söylüyorum, benden önce ve bana rağmen var olanı gördüğümüzü söylüyorum. Hani bu nokta da ben doğruyu söylemeye çok yakın buluyorum belgesel sinemacıları. Kendi bakış açımla ama kendimden önce var olanı görerek onun doğru olduğu bilerek söylüyorum. Çünkü o doğru. Benzetmeyi öyle yapmaya çalıştım. Bunu doğrulamanın yolu ne? Belgesel sinemacılarla diğer sinema alanlarının en azından bir filmi ortaya çıkardıktan sonra ne şekilde tartışıldıklarını kamu da nasıl tartışıldıklarını incelersek görebiliriz. Kurmaca sinemada olan şeyler daha çok yorum üzerine, oyunculuk üzerine, senaryonun dramatik yapısı üzerine ve çok az bir miktarda da gerçeklik üzerine tartışılır. Daha çok hani oradaki dünyaya inanmakla inanmamanın arkasındaki gerçeklik olarak gerçekliği oralarda görebilir. Ama daha çok bir sanat formunun şey olarak tartışıldığını söyleyebilirim; o sanatın kendine özgü araçları açısından ya da onu birleştiren parçalar açısından dramatik yapı ona benzediği gibi. Ama belgesel sinema her şeyden önce ele aldığı olguyla tartışılan bir sinema. Yani Nuri Bilge Ceylan'ın sinemasını örnek veriyorum bir kasıt olarak değil. Biz, Bir Zamanlar Anadolu'dayı ya da Kış Uykusu'nu konusuyla tartışmıyoruz ki. Nuri Bilge Ceylan'ın sinemasını anlatırken konu bize araç oluyor. Ama Hasan Ôzgen sinemasını belgesel sinemada tartışırken Hasan Özgen'in sinemasını önce bir kenara koyuyoruz. Hasan Özgen'in ele aldığı olguyla başliyoruz. Ben böyle bir ayrımı az da olsa yapabiliyorum, yapılması gerektiğini de düşünüyorum. Böyle olunca belgesel sinemacının anlatmaya çalıştığ1 o doğru ya da hakikat, kamunun önüne çıktığ1 andan itibaren tartışılır olmayı doğrudan hak ediyor. Ve belgesel sinemacının doğru olduğunu bildiği şeyi doğru olduğu için anlattığını varsayıyorum. Ve bu doğru olduğunu bildiği şey doğru olduğu için de ortaya çıktığı ya da paylaşılmaya kalkıldığı her yerde, belgesel sinemacı her zaman bir risk alıyor. Nedir bu risk? Sizi çektiği anda bir risk almıorsunuz. Çektiği an sadece o gerçekliğin 
bir belgeye dönüşmesi ya da o belgenin ikinci kez bir belge haline dönüşmesi. Ama onu kamunun önüne çıkardığınızda asıl doğruyu söylemeye başlıyorsunuz. Filmin içinde kaldığınızda sorun yok. Parrhesia denen hakikati söyleyen kişi de ne zaman kamusal alana çıkıp o tiyatroda insanların önünde bunu söylediği zaman nasıl süreci tamamlıyorsa belgesel sinemacı da filmini izleyiciye ulaştığında doğruyu söylemiş oluyor. O zaman filmi yaptığınız anla filmi gösterdiğiniz an arasında ciddi bir zamansal fark var. Canlı yayın yapmadığınız sürece. Belgesel sinemada da canlı yayın diye bir kavram şu anda dilimden çıktı ama ben böyle bir tartışmaya girmekten yana değilim. Böyle bir şey de komik kalacaktır belki. Biz filmi yaptıktan epey bir zaman sonra seyirciyle buluşuyoruz. Biz değil bizim söylediğimiz bizim doğru dediğimiz kavram orda izleyiciyle karşılaşıyor. Az önce bizim de söylediğimiz gibi, ele aldığımız olguyu başlıyor tartışmaya, ölçmeye, biçmeye. Çok sonra bizim sinemamıza ilişkin cümleler kurulmaya başlıyor. Ve bütün bunlar olurken belgesel sinemanın çok sınırlı alanlarda doğruyu söyleme fırsatı yakaladığını görüyoruz. Festivaller, gösteriler, nadiren de olsa televizyonda bunu söyleme şansımız oluyor. Yaptığımızla gösterdiğimiz zaman arasında konjonktürel olarak bir değişim her zaman yaşanıyor. Devletin baskı araçları belgesel sinemayı her zaman bir kılıç gibi takip eder, ediyor da. Bunu ne yapıyor. Biz gözaltına alınmıyoruz, dayak yemiyoruz, işkence edilmiyoruz ama bizim kamusal alanda varlığımız herhangi bir şekilde destek görmüyor. Ya da izleyiciye benim doğru söyleme kanallarım çok sınırlı kalıyor. Özel gösteriler, işte orada da ben başka bir kavram söylüyorum: "Cemaat Seyircisi." Filmler o cemaat tarafından seyrediliyor. Yani eşcinsellik konulu bir film yapıyorsun eşcinseller seyrediyor. Zaten onlar olgunun içindeler. Süryanilerle ilgili film yapıyorsun Süryanilere ulaşıyorsun, kadın hakları ile ilgi film yapıyorsun zaten bu alanda çalışan kadınlara gösteriyorsun. Çünkü senin doğruyu söyleyeceğin öbür alanlar açık değil. Yani televizyonlar sana kapalı. Sıcak bakmiyor ya da geçenlerde Hollanda'dan öyle bir teklif geldi. Yanlış hatırlamiyorsam yüz yirmi euro mu ne veriyorlar bir filmi göstermek için. Senin uğraşmana değecek bir rakam değil. Aman bu filmi gösterin de ben maddi karşılığında değilim. Alın yeter ki ben doğruyu söyleyecek bir yer bulayım, ben kendi doğrumu söyleyeyim diyorsun da bu da çok sınırlı. Bakın bu anlamda devletin ideolojik aygıtlarını söylemiyorum devletin baskı araçları sizi gerektiğinde kovuşturabiliyor. Çekim aşamasında engel olarak da görebilirsiniz, bunu yaptıktan sonra bir yerde gösterdiğiniz de karşınıza çıkabilir, gösterdikten daha sonra hakkınızda bir şikâyet ortaya çıkabilir, yıllar geçtikten sonra da linç edilebilirsiniz. Bunun illa var olan şu anki siyasi yapıyla ilişkilendirilmesine de gerek yok. Belgesel sinemanın tarihi bu tür örneklerle dolu. 1933-34 de "Türkiye'nin Kalbi Ankara" diye bir film yapiliyor. Bu film cumhuriyet kadroları tarafından o on yıldaki Türkiye'nin geliştirdiği o ülkeyi o devleti anlatmaya dönük bir yanıla propaganda amacıyla yapılan bir film. Hani neydik ne olduk filmi. Türkiye'de o sırada zaten belgesel sinema kavramından söz etmek mümkün değil. Sinema bile çok cılız. Ne yapılıyor Sovyetler Birliği'nden bir ekip getiriliyor ve ona çektiriliyor. Ve o film ciddi şekilde sinemada gösteriliyor yani kamusal alana çıkıyor. Sonra unutuluyor o film. Taa ne zaman; TRT kurulduktan sonra. 33 nere 1968 nere. Dönemin genel yayın il müdürü Mahmut Tali Öngören sizin çalıştığınız Gazi Üniversitesi, Basın Yayın Yüksekokulu hocalarından, Mahmut hoca aynı zamanda TRT'nin İlk Genel Yayın Müdürü ya da televizyonun yanlış söylemiş olmayayım. Arşivden buluyor bu filmi gösteriyor. Ya, o film yapıldıktan kırk sene sonra arkadaşlar. Direk dava açılıyor kominizim propagandasından. Gerekçe ne orda işte çobanın elinde tuttuğu değnekle ya da çiftçinin elinde tuttuğu orakla kominizim propagandası yapıldığı ya da işte yazıların Kiril alfabesi ile olması, kominizim propagandası sayılıyor. Komik ama böyle. Anlatabiliyor muyum? O anlamda da belgesel sinemacı söylediği andan itibaren o riski almış oluyor ama bence eğer kişi Parrhesia' yı yerine getiriyorsa yani kendisini bir Parrhesiastes olarak görebiliyorsa bu riski zaten baştan kabul ediyor. Bu da işte belgesel sinemacıyı diğer sinemacıdan ayıran bir şey. Burada bizim temel kılavuzumuz kendi etik anlayışımız ve kendi vicdanımız. Bizi başka hiçbir şey yönetmez. Ben doğru bildiğimi doğru bildiğim için doğru biliyorum ve ben bunu anlatıyorum. Bunu anlattığım andan itibaren de gelecekte de herhangi bir zaman diliminde bu anlattığım doğru nedeniyle mutlaka eleştirilebilirim, karşı çıkılabilirim, soruşturulabilirim, filmim yok edilebilir. Bu riski daha çekmeye başladığım andan itibaren alan bir nesneyi temsil ediyorum sevgili Işkın hocam. Umarım yine gevezelikle boğmadım.

Işkın Özbulduk Kılıç: Çok güzel anlattınız hocam. Çok teşekkür ederim. 
Kurtuluş Özgen: Duygulanım felsefeye Spinoza ile girdi diyebiliriz. Ulus Baker'e kadar uzanan bir süreç var. Buradan da son filminizle ilgili soruya bağlamak istiyorum. Masumiyet belgesel sinemacı ve şair Hasan Özgen üzerine bir belgesel film ama biyografi belgeseli değil, eserleri üzerine değil. Bence Türk belgeselinde, belgeselciliğinde ilk defa karşılaştığımız bir örnek. Ben filmi şöyle tanımlıyorum: 'ontolojik bir portre'; Hasan Özgen'in duygu-lanım ve kavram evrenini merkeze alıyor. Sorum şu; nasıl oldu bu?

Hakan Aytekin: Şöyle oldu. Bir benim altmış yıllık yaşam öyküm ama daha şeyi hani bu filmi tetikleyen kırk üç yıl artı bu film. Hasan Özgen'le benim yolum çok eskiden kesişti. Yani 1970'lerin sonunda başlayan bir ilişki var. Kırık yılı aştı. Benim ilk ustalarımdan biri Hasan Özgen. Ben onun kamerasını çok taşıdım kamera asistanlığını yaptım. Sonra filmlerinde kameramanlık yaptım sonra onunla ortak filim de yaptım, onunla ortak film de yönettim. Dolayısıyla Hasan Özgen'le ciddi bir yaşama ortaklığı deneyimim oldu. Benzer şeyle sinirlendik benzer şeylerden keyif aldık benzer şeyleri anlatmaya çalıştık benzer doğruların etrafında döndük. Yazdık çizdik okuduk konuştuk. Tabii ki Hasan Özgen'i ciddi şekilde tanımış olduk. Tanıdığım bir şeyi anlatmak bu anlamda tabii ki çok kolay. Ama tanıdığım bir şeyi anlatmak en başta konuştuğumuz kavrama dönersek didaktik olarak çok mümkün. Hasan Özgen 1947 yılında Milâs'ta doğdu işte Milâs ortaokulunda şunu yaptı, lise de bunu yaptı, şunlar bunu yaptı, bunlar bunu yaptı diye anlat son derece kolay. Böyle bir Hasan Özgen anlatılmaz mı anlatılır. Hasan Özgen'in ne tür filmleri yaptığını gösteremez miyiz, neler yazdığını anlatamaz mıyız, anlatırız. Ve gayet güzel didaktik değil poetik olarak da anlatırız. Böyle baya da malzeme verecek bir hayat var karşımızda. Ama bütün bunlar Hasan Özgen'i, Hasan Özgen yapan şeyi anlatmaya yetmez. Benim çıkış noktam bu. Yani burada aklıma Mutlu Parkan hocam geliyor onu bir kere daha anmış olayım. Onun verdiği çok güzel bir örnek var "bir fabrikanın içine onlarca kamera koyup hiç müdahale etmeden fabrikada olan biteni onlarca kamera ile çeksek bile sermaye yapısında tek bir şey söylemiş olmaz o görüntüler," der. Şimdi aklıma geldi demek ki benim bilincimde böyle bilgiler var. Hasan Özgen'i anlatmak, Milâs 1947 doğduğunu anlatmak değil. Hasan Özgen'i var eden şey ne ve Hasan Özgen bunu nasıl yorumluyor? Sadece şey değil benim derdim Hasan Özgen'i var edeni anlatmak değil. Hasan Özgen kendisiyle bunu nasıl bir muhasebe içinde nasıl dışarıya çıkarabilecek. O anlamda filmin katmanlarından birini düşündüm ve Hasan Özgen'in Aşkın Seferberlik Hali kitabı çıtı̆̆ında, ben o kitabın içinde bazı şeyleri zaten daha önce defalarca Hasan Özgen' den duymuş bir adamdım ama sözdü sonra yazı haline geldi, belge haline geldi. Bu neyi sağladı bana; iki de bir o belgeye dönüp benim yüzleşmemi sağladı. Ben iki de bir dönerim hakikaten yatak odamda komodinin üstünde değişmeyen kitaplardan biri nedense orada duruyor. Beni bir şekilde yakalamış. Yani benim çok sevdiğim bir abim olduğundan değil, içindeki dünyada, imgelerde beni yakaladığından. Sonra ben Hasan Özgen filmini çekmeye karar verdiğimde, Hasan Özgen'i değil Hasan Özgen'in imge dünyası üzerinden onu var eden, sizin kavramınızla onun ontolojisi üzerine giden bir şey yapabilmek için yola çıktım ve bunu Hasan Özgen'le paylaşmadım. Sadece "seninle film çekmek istiyorum," dedim. $\mathrm{O}$ da "olur ama ben Bodrum' dayım, İstanbul'a gelmem bu koşullarda zaman alacak, sonra görüşüz" falan dedi. "Yok ben İstanbul' da çekmeyeceğim orada çekeceğim" dedim. O zaman "istediğin zaman gel" dedi. "İşte falanca yerdeyim, yoo oraya da gelmeyeceğim" dedim. "Ben seni Milas'ta çekmek istiyorum" dedim. Hasan Özgen şaşırdı. "Aa iyi" filan, "Milâs" dedi. "Evet, seni Milas'ta çekmek" istiyorum. "İyi” dedi, sözleştik gittim çekime. Koca konakta yani Hasan Özgen'in ontolojik olarak izlerinin bulacağım yerde Hasan Özgen'i çekmeyi kafama koydum ve gitmeden de Hasan Özgen'e belgelerle değil imgelerle gitmeye karar verdim. Ve ben o imgelerin sıralamasını yaptım. Az önce örneğini verdiğim siftahsız kepeksiz dükkânlar imgesi gibi. Ve koca konakta buluştuk. Kapısının asma kilidinin beraber açtık. Tabi Hasan Özgen refleks olarak binaya doğru yöneldi. "Hayır binaya girmeyeceksin" dedim. "Niye?" dedi. "Önce görüşmeler yapacağız sonra binaya gireceksin," dedim. Ve Hasan'ı onkolojik mekâna mekânın avlusuna hapsettim. O mekân ve kendi zihnindeki o soyut mekân soruları tamamen o imgeler üzerinden. Tabii ki en büyük şansım işte Hasan Özgen gibi oldukça filozof bir adamın bu soruları çok layıkıyla cevap vermesi, bu büyük bir şans. Ama şans olmanın ötesinde ben böyle bir adamla karşı karşıya olduğumu bildiğim için böyle anlatmazsam yanlış olur. O da bir yönetmen sezgisinin bakışının tezahürü diyebilirim, biraz da kendime yonttum. Orada ben görüşmeleri yaptım birkaç saat süren. Sonra mekânın içine Hasan Özgen'le girdim. O imgeden bahsedilen şeylerin artık belge olarak karşılığının ne olduğunu bana duvarlar 
veriyordu, sofa veriyordu, merdiven veriyordu. Unutulmuş mekânlar veriyordu. Kırılmış camlar, çatlamış duvarlar veriyordu. Ama bütün anlatıya dönüp baktığımda ben yine Hasan Özgen'i anlatmadım. Hasan Özgen'in geçirdiği çocukluk yıllarını, işte belki altmışlı yetmişli yıllara kadar yoğun ama ondan sonra da kopmayan koca konak etrafındaki dünyayı, aslında kopmayan Türkiye'nin kırk beş sonrası doksan arası toplumsal tarihini anlattım ben orada. Yani daha doğrusu onu anlatmaya çalıştım. Anlattım diye kendime değer biçmeyeyim, anlatmaya çalıştım. Çünkü Hasan Özgen'in söylediği Milâslı zengin Tekirdağ Çorlu'da da vardı ya da işte Samsun Havza' da da vardı veya Niğde Bor'da da vardı. O tarihlerde o mahalle ve evin, insanı var ettiği ve geleceğini kurduğu ortaklaşa yaşamda, pazar ekonomisine doğru evrilmeye başlayan bir Türkiye ile oraların pazarlaşmasını, bir yandan oraların dışarıya taşarken bir yandan da dışarının oraya zuhur etmesini Hasan Özgen'in şiiri ile anlatmaya çalıştım. Ve muhteşem bir şey bu "Masumiyet" adını taşıyan bir şiir. Ve hiçbirimiz masum değiliz bu sürecin içinde. Ben bir tür onu, o porteyi ontolojik olarak var eden bir dünyayla aslında son elli yılımızın bir muhasebesini yapıp herkesin kendisini ne kadar masum olarak bulabileceği bir anlatı ortaya koymaya çalıştım. Sürçülisan ettiysem af ola ama derdim buydu.

Işkın Özbulduk Kılıç: Aslında yine cevaplandığını ama eksik olduğunu düşündüğüm bir soru. Abbas Kiarostami manipülasyonun, hakikati film içinde bulmanın bir yolu olduğunu ifade etmektedir. Sinemanın gerçekle ilişkisi ile ilgili tartışmalar açıkça veyahut da örtük olarak manipülasyon meselesiyle ilişkileniyor. Mesela Flaherty, “bazen gerçeği söylemek için yalan söylemek zorunda kalırsınız" diye açıklıyor. Şimdi buradan hareketle, eğer film, kurmaca ya da belgesel fark etmeksizin bir yaratımsa -burada yaratımı hem var etmeyi hem de yaratıcının ettiği müdahaleyi kastederek kullanıyorum- o zaman film içinde kaçınılmaz olarak manipülasyon içeren bir anlatıdır. Siz bu hususta ne düşünüyorsunuz? Belgeselin bu organik ve sahte, tabiri caizse doğru ile yalanın içindeki dengesi hakkındaki fikirlerinizi çok merak ediyorum. Belgeselin mevcut kimliği ile manipülasyon arasında bir ilişki mevcut mudur sizce? Yoksa doğru yine de her yaratıma rağmen (filme ait bir) doğru mudur?

Hakan Aytekin: Sanat manipülatiftir. Bir kere bunu kabul edelim. Sanat hiç masum veya kendi başına çok saf pür bir şey değil ki. Çünkü sanatçı diye bir şey var onu yapan. O insanın bir derdi var o derdi ortaya koyarak bunu herhangi bir araçla, filmle, heykelle, şiirle, dansla başkalarına anlatıp onların harekete geçmesini ister. Davranış olarak ister. Duygulanım yaratsın, harekete geçirsin ister. Ben yoksa niye yapayım. Ha, şunu yapabilirim. Resmimi yaparım, evde duvara asarım, geçerim karşısına hayran hayran seyrederim. Bu o zaman bir sanat olmuyor. Sanat ancak onu başkalarıyla paylaşmaya başladığınız andan itibaren kendi sürecini başlatmış oluyor. Siz fırçayı elinize alıp tabloya dokunduğunuz andan itibaren değil; tablo bittiğinde o bana göre hâlâ bir sanat değil. Ne zaman tabloyu duvara assanız, sokağa afiş olarak bastınız yani redüksiyonunu koydunuz ya da ondan biri film yaptınız, o zaman başlıyor zaten onun hayatın içindeki macerası. Bu da sanatçıdan bağımsız bir şey değil. Sanatçının bizzat hayatı manipüle etmesi. Ama burada şöyle bir sorunla karşı karşıyayız. Bir yandan gerçek diye bir kavramla bir yandan da manipülasyon. Ne yapacağız şimdi? Bu hakikaten ciddi bir sorun. Evet, manipüle ediyoruz. Neyle manipüle ediyoruz? Kendi dünyaya bakışımızla manipüle ediyoruz. Bizi belirleyen kendi dünya bakışımız. Hal böyle olunca orda öznellik kavramı ortaya çıkıyor ve o öznelliğin içinde de biz, o gerçekliğe ama o Parrhesia kavramına da gönderme yapıyorum, ona ihanet etmemeye çalışıyoruz. Burada çok önemli bir fark var Işkın hocam. Inançla gerçekte olan arasındaki mesafeyi ne kadar kısaltabilirsek o zaman yerini buluyor manipülasyon mümkün olduğu kadar. $\mathrm{O}$ bizim anlatmaya çalıştığımız doğruya götürmeye yarıyor. Belgesel sinemada bu alandan çok büyük riskler taşıyan, çok yanlış anlamlar yüklenen, çok kutsi görünen bir sinema ama çok büyük yanlışları da kendi içinde taşıyabiliyor. O manipülasyon az önce de söylediğim gibi çok propagandif noktaya çekmek son derece kolay. Burada mesela hiç tartışılmayan kavramlardan birine dikkat çekmek istiyorum. Sanırım makalede de değinmiştim buna. Biz Fly On The Wall şeklinde hani belgesel sinemaya hiç sevmediğim bir tabirle yaklaşırsam kamerayı koyduk mobese kamerası gibi çektik. Isste Ankara' da Hacı Bayram Veli Üniversitesi'nde hoca olmak sorunu üzerinde iki tane hocaya kamerayı uzattık. İki tane hoca da Ankara Hacı Bayram Veli Üniversitesi'nde hoca olmayı anlattı bize. İşte altında da yazıyor Doçent Kurtuluş Özgen, Araştırma Görevlisi Işkın Özbulduk Kılıç. Bu zaten sizi yeterince inandırıcı kılıyor belge olarak. Parrhesia siz oluyorsunuz artık ben değil. Siz doğru bildiğinizi söylemeye başlıyorsunuz. Ben sizin doğru bildiğinizi, 
ben evet bu doğrudur diye anladığım için ben bunu alıp seyirciye aktarıyorum. Parrhesiastes olmam aslında birazda sizin Parrhesia'yı ifade etmenizden başlıyor. Orada biz iş birliğimiz bir suç ortaklığımız var. Ama kimse şunu sormuyor. Ya, hakikaten Kurtuluş Özgen ve Işkın Özbulduk Kılıç Ankara Hacı Bayram Üniversitesi'nde mi o uzman ya, ikisinin altına yazdık ya Ankara Hacı Bayram Üniversitesi diye. Siz artık Parrhesia' yı doğrudan temsil eder haline geliyorsunuz. Enes Batur'un çok sevdiğim bir yazısında rastladım, her yerde de söylüyorum. O kadar hoşuma giden bir cümle ki. "Evet, tanıklar bunları söylüyor ama tanıklara kim tanıklık edecek." Orada bir tek tanıklık var. Kendi vicdanımız ve etik anlayışımız. Manipülatifiz ama Parrhesia'yı dile getirdiğimiz, onu bir Parrhesia olduğunu bildiğimiz için söylüyoruz, ona inandığımız için değil. O doğru olduğu için söylüyoruz. Bu kadar da saf bu kadar da nahifiz. O yanıyla da belgesel sinemanın böyle bir vicdanı muhasebe ile değerlendirilmesinde de yarar olduğuna inanıyorum. Söyleyeceğim bu kadar.

Işkın Özbulduk Kılıç: Çok teşekkürler hocam.

Kurtuluş Özgen: Sayın Aytekin ben sizi hocanız Ünsal Oskay'ın tabiriyle belgesel sinemamızın "yıkanmak istemeyen huysuz çocuğu" olarak tanımliyorum... Derinlikli bir söyleşi oldu. Hakan hocam dergimiz adına size çok teşekkür ediyoruz.

Hakan Aytekin: Türk sinemasına çok büyük katkıları olan usta görüntü yönetmeni İlhan Arakon Amca'yı İlhan Amca'yı anarak bitirmek istiyorum. Ünsal Hocayı söyledi Kurtuluş hoca. İlhan Arakon da hocaydı. O arada bir gelir bize takılırdı. Üstelik kendisi de bu işi yaptı. Pek çok belgesel sinema da pek çok filmde görev almıs birisidir. Eğilirdi böyle "oğlum sizin yaptığınız iş, Mekke'de domuz kasaplığı" derdi. Onu da böylece anmış olalım.

Kurtuluş Özgen: İlhan hocayı da saygıyla anıyoruz.

Hakan Aytekin: Çok teşekkür ederim böyle bir söyleşi gerçekleştirdiğimiz için. Umarım belgesel sinemayı naçizane kendi bakışımla anlatabilmişimdir. 